\title{
Penerapan Restorative Justice pada Peradilan Pidana Anak Terkait Pembaharuan Hukum Pidana di Indonesia
}

\author{
Ryan Aditama ${ }^{1^{*}}$, Novia Yolanda ${ }^{2}$ \\ ${ }^{1,2}$ Fakultas Hukum Universitas Batanghari \\ Jalan Slamet Riyadi Broni Kota Jambi Telp: (0741) 65351 \\ ${ }^{*}$ Correspondence email: ryan.aditama31@gmail.com
}

\begin{abstract}
Abstrak. Landasan yang melatarbelakangi dari konsep restorative justice ini adalah bagian dari suatu pendekatan yang menitikberatkan terhadap keadaan dimana agar menciptakan keadilan bahkan keseimbangan terhadap pelaku yang melakukan perbuatan pidana, dan juga bagi hak-hak korban. Prosedur maupun tata cara serta peradilan pidana yang mengarah dari asas pemidanaan diubah kearah proses percakapan secara kekeluargaan serta mediasi agar terciptanya kesepakatan dan terhadap penyelesaian perkara pidana tersebut yang menciptakan kearah keadianl serta akan setara bagi pihak korban maupun terhadap pihak pelaku tindak pidana tersebut. Konsep Restorative justice ini secara tersendiri mempunyai makna dimana keadilan yang akan diperbaiki, serta restorasi disini mempunyai arti lebih luas lagi terhadap apa yang dikenal pada proses peradilan pidana konvensional atau pada umumnya yang berlaku selama ini dengan adanya restitusi atau biasa disebut dengan ganti rugi untuk korban. Konsep restoratiive justiche ini jika dimasukkan dalam sebuah sistem pada peradilan kepidanaan anak dianggap secara baik terhadap penerapnnya, karena restoratiive justiche berguna dalam rangka menghindarkan terhadap anak terhadap sistem pemidanaan dan akan diganti pada pola pembimbingan kepada anak tersebut.
\end{abstract}

Kata Kunci: Restoratiive Justiche; Pembaharuan Hukum Pidana

\begin{abstract}
The foundation behind the concept of restorative justice is part of an approach that focuses on situations where in order to create justice and even balance the perpetrators who commit criminal acts, and also for the rights of victims. Procedures and procedures as well as criminal proceedings that lead to the principle of criminalization are changed to a process of family conversation and mediation in order to create an agreement and to resolve the criminal case which leads to crime and will be equal for the victim and the perpetrator of the crime The concept of restorative justice in itself has a meaning where justice will be repaired, and restoration here has a broader meaning to what is known in conventional criminal justice processes or in general that has been applicable so far with the existence of restitution or commonly referred to as compensation for victims. This restorative justiche concept, if included in a system in juvenile criminal justice, is considered well for its application, because restorative justiche is useful in order to prevent children from facing the criminal system and will be replaced in the guidance pattern for the child.
\end{abstract}

Keywords: Restorative Justice; Criminal Law Reform

\section{PENDAHULUAN}

Ketika membahas mengenai kejahatan, maka yang menjadi konsep utamanya merujuk pada pelaku kejahatan yang lazimnya masyarakat cenderung dinamakan dengan kata penjahat, pelaku kriminal, bahkan lebih prontal dengan kata sepertisampah bagi masyarakat serta masih banyak lagi ungkapan bagi pelaku kejahatan ini. Masyarakat yang pada umumnya, atau lazimnya, melihat bahwa pelaku kejahatan merupakan faktor munculnya kejahatan tersebut. Hal ini membuat aparat penegak hukum mengarahkan pola tindakan penghukuman kearah tindakan pelaku semata. Dengan melakukan penghukuman terhadap para pelaku, aparat menganggap akan dapat memperbaiki keadaan yang lebih baik lagi terhadap luka maupun penderitaan bagi korban ataupun kelainan terhadap tindakan bagi perilaku yang melekat bagi yang melakukan kejahatan tersebut.

Faktanya pada kenyataan sekarang, semakin maraknya kasus kekerasan bahkan penyelewengan kekuasaan hingga tindakan semena-mena bagi pemangku jabatan yang menyebabkan perilaku viktimisasi terhadap terpidana. Jika dikaitkan pada Konsep Kelembagaan Pemasyarakatan saat ini yang berada di bagian empirisnya, merupakan sama dengannya terhadap penjara. Bahkan ada anggapan yang menyatakan bahwa Lembaga Pemasyarakatan justru merupakan "sekolah kejahatan" artinya mereka yang awalnya hanya mencuri motor, setelah keluar dari Lembaga Pemasyarakatan justru naik tingkatnya mencuri mobil begitulah ungkapannya. Yang sering terjadi menyebabkan perilaku seseorang akan tambah jahat setelah mengalami pola pemidanaan pada tingkatan penjara di Kelembagaan Pemasyarakatan saat ini. Dari kondisi inilah mengakibatkan salah satu faktor yang besar seorang mantan narapidana akan mengulai kejahatan lagi, baik yang telah dilakukan sebelumnya, maupun tindak pidana lainnya yang belum pernah dilakukannya. Yang dalam bahasa hukumnya disebut dengan kata residivis.

Lebih dalam lagi Hulsman mengatakan: "the criminall justice systeem as a social problema". Dia mengoreksi yang mengarah pada tingkatan pola menerapkan bagian dari sanksi sehingga menimbulkan konsep penderitaan dimana akan berdampak kepada moralitas ataupun kearah materilnya, terhadap kehidupan ekonomi, baik bagi keluarga 
maupun pandanga masyrakat bagi dirinya tersebut. Pada konsep pendekatan terhadap sistemn peradilan hingga sampai saat ini susah untuk dikontrol, mengendalikannya serta cenderung kearah pada kecacatan (criiminal justice appproach its fundamentaly flaweid), dikatakan "does'nt worked inthe terms of it's own decllared aimst" atau kegagalan dengan tujuan yang menyatakan dia sendiri.

Sedangkan apa yang dikatakan oleh John Delaney, menyatakan bahwa pengembalian bagi seorang yang menjadi mantan narapidana atau telah melakukan proses pidana sehingga kembali pada kehidupan masyarakat diharuskan pada asas selff realisatiion on proces, adalah satu masa dimana dengan memprioritaskan mengarhkan keperhatian dengan seksama pengalamannya, nilai yang ada, harapan serta cita-cita dari seorang narapidana itu sendiri, dan juga merupakan bagian dalam hal ini menyangkut latar belakang budaya yang melekat pada dirinya, kelembagaan serta keadaan masyarakat yang merupakan asal dia sebelumnya, dilain pihak apa yang telah dikatakan David Rothman menyatakan rehabilitasi adalah pembohongan yang telah diungkapan. Dia mengatakan seperti itu sesudah dia mengetahui dan menyaksikan sendiri fakta yang terjadi sesungguhnya bagi penjara itu sendiri yang memisahkan antara penjahat terhadap kehidupannya mengakibatkan ketidakwajaran membuat kondisi dia sendiri tidak dapat beradaptasi kembali dengan lingkungan yang ada pada saat dia telah keluar dari proses pemidanaan penjara yaitu terutama paradigma negatif oleh masyrakat bagi narapidana itu sendiri.

Ternyata, beberapa persoalan tentang kejahatan yang berkaitan dengan Sistem Peradilan Pidana Indonesia harus berpores dan berujung pada hukuman penjara. Nyatanya, hukum penjara adalah bukan merupakan upaya yang terbaik atau menjadi solusi terbaik dalam menanggulangi kejahatan, terutama pada tindakan yang mengarah pada kejahatan tersebut sehingga "dampak" yang ditimbulkan terhadap diri korban sendiri maupun bagi masyarakat itu sendiri yang masih bisa dilakukan konsep restorasi dengan harapan bahwa kondisi yang sebelumnya "dalam kondisi rusak" menjadi dapat diperbaiki kepada keadaan sebelumnya dimana sebelum terjadinya tindak pidana itu, dan merupakan sarana untuk menghilangkan dampak negatif dari proses hukuman penjara itu sendiri. Jika dikaitkan dengan bebarapa konsep kejahatan yang ada atau dapat disebutkan dapat dilakukan konsep restorasi tersebut, disinilah muncul konsep baru dari tindakan penghukuman yang dikatakan dengan sebuah konsep restorative justice, di mana terkait pelaku tersebut akan diupayakan kedalam hal membenahi atas dampak yang diakibatkan dari dirinya kepada si korban, keluarga dan juga masyatakat disekitar. Yang menjadi point pertamanya terhadap "a meeting place for people" yang bertujuan untuk mencari jalan keluar terhadap keterkaitan antara solusi memperbaiki dan membenahi permasalahan serta kerugian yang timbul atas kejahatan tersebut.

Keadilan pada konsep yang dilandaskan pada konsep kearah sifat damai terhadap diri pelaku, maupun korban itu sendiri bahkan kepada masyarakat disekitarnya yang akan menjadi bagian dari sifat moral etika restoratiive justiice, atas dasar tersebutlah bahwa keadilan tersebut sebagai konsep dari "Justice Peache Principple". Pada prinsipnya menyebutkan terhadap keadilan bahkan perdamaian itu sedniri pada hakikatnya akan sulit untuk dijauhkan antara keduanya. Konsep dari sebuah perdamaian dengan tidak mengikutsertakan sebuah keadilan didalamnya itu adalah sebuah penindasan bagi seseorang, dan begitupula jika rasa keadilan tanpa adanya tindakan perdamaian itu akan mengakibatkan dampak dengan apa yang disebut dengan penganiayaan atau dengan tekanan. Dapat dikatakan dengan Justice Peache Principple atau bahasa lainnya apa yang dinamakan dengan Justice Peache Ethiicht oleh karena bagian dari pendekatan itu sendiri terhadap bagian dari kejahatan kedalam Restoratiive justiche yang bertujuan sebagai konsep bagi pemulihan dari kerusakan-kerusakan yang diakibatkan atas tindakan kejahatan itu sendiri (it's an atempt too recovery justiche), tindakan ini di tujukan agara dapat menyatuhkan baik pihak korban, pihak pelaku bahkan masyarakat itu sendiri.

Yang menjadi permasalahannya dimana konsep peradilan yang sudah diarahkan pada pola dengan retributiive justiche dimana padangan bagi tindakan kejahatan itu sendiri sebagai sebuah pelanggaran yang ditimbulkan oleh negara. Apa yang ditujukan oleh pendekatan ini sendiri mengarahkan kepada masa lalu serta yang memiliki tujuan kearah untuk memilih kepada siapa yang akan dilimpahkan keasalahan kepadanya serta model pidana apa yang didapatkannya. Disisi lain terhadap konsep restoratiive justiche, Hingga akan menampilkan secara yuridisnya maupun ilmiah dari konsep peradilan restoratif agar dimasukkan kepada konsep penegakan hukum yang ada di Indonesia saat ini.

Landasan yang melatarbelakangi dari konsep restorative justice ini adalah bagian dari suatu pendekatan yang menitikberatkan terhadap keadaan dimana agar menciptakan keadilan bahkan keseimbangan terhadap pelaku yang melakukan perbuatan pidana, dan juga bagi hak-hak korban. Prosedur maupun tata cara serta peradilan pidana yang mengarah dari asas pemidanaan diubah kearah proses percakapan secara kekeluargaan serta mediasi agar terciptanya kesepakatan dan terhadap penyelesaian perkara pidana tersebut yang menciptakan kearah keadianl serta akan setara bagi pihak korban maupun terhadap pihak pelaku tindak pidana tersebut. Konsep Restorative justice ini secara tersendiri mempunyai makna dimana keadilan yang akan diperbaiki, serta restorasi disini mempunyai arti lebih luas lagi terhadap apa yang dikenal pada proses peradilan pidana konvensional atau pada umumnya yang berlaku selama ini dengan adanya restitusi atau biasa disebut dengan ganti rugi untuk korban. 
Dalam hal ini terlepas dari suatu pandangan yang menyatakan terhadap sebuah peristiwa yang diakibatkan oleh kejahatan, bahkan timbulnya penderitaan bagi orang yang telah terlibat dirinya menjadi korban, hal ini akan membuat tidak hanya bagi orang itu sendiri, melainkan juga akan berpengaruh pada orang di lingkungan sekitarnya. Dan juga akan berpengaruh bagi masyarakat serta dalam tatanan negara yang termasuk lingkupan jauh lebih luas lagi. Pada lingkup peradilan pidana, korban itu sendiri hanya diurus atau ditempatkan sebagai pada saksi korban saja, dan tidak berhak untuk mengikutkan maupun ikut berperan aktif dalam sebuah proses sidang pengadilan. Terlihat jelas bahwa, para penegak hukum itu sendiri hanya memposisikan korban sebagai bagian dari instrumen untuk membantu mereka dalam hal melakukan penghukuman ataupun penjatuhan pidana terhadap pelaku tersebut, dan tanpa pernah melihat jauh lebih lanjut kepada sumbangsi yang akan mereka berikan bagi hak maupun kepentingan korban tersebut.

Namun pada akhirnya, dalam sebuah konsep apa yang dinamakan dengan restoratiive justiche ini akan meliputi terhadap pemulihan atas hubungan yang baik bagi pihak korban maupun pihak pelakunya, atas dasar untuk memulihkan hubungan ini akan berlandaskan pada kesepakatan mereka bersama bagi korban serta pelaku. Untuk dari pihak korban itu sendiri dapat mengajukan mengenai perihal kerugian yang ditumbulkan atas perbuatan tersebut serta pelaku itu sendiri pun akan diberi kesempatan untuk memperbaikinya seperti keadaan semula, dengan cara ganti kerugian, proses perdamaian, hukuman kerja sosial, serta perjanjian lainnya yang akan dibuat oleh kedua belah pihak. Proses ini akan menjadi sangat penting, karena sesungguhnya pada proses pemidanaan yang pada umumnya atau berlaku saat ini tidak akan memberi sebuah ruang kepada kedua pihak yang terlibat dalam masalah tersebut, antara korban serta pelaku agar dapat berpartisipasi aktif untuk melakukan penyelesaian terkait masalah yang mereka hadapi.

Terkait konsep ini sudah banyak di berbagai negara sudah memulai untuk memikirkan dari sebuah alternatif dalam penyelesaian sebuah konflik yang terjadi yang berkembang pada lingkungan masyarakat. Terkait dengan apa yang termuat pada konsep pendekatan restoratiive justihce ini, maka pendekatan ini akan menitikberatkan pada peran dari partisipasi aktif secara langsung baik dari pihak pelaku, pihak korban serta lingkungan masyarakat yang pada proses penyelesaiannya tersebut termasuk dalam kategori kasus kepidanaan.

Terkait dengan kejahatan, akhir-akhir ini banyaknya kasus yang timbul bersumber dimana pelakunya adalah anak. Disisi lain pada anak yang melakukan pelanggaran terkait hukum itu sendiri (terkait anak yang terlibat atau sebagai pelaku tindak pidana) setiap tahunnya ataupun dalam konteks bulannya terjadi peningkatan yang sangat signifikan. Terkait dengan itu, maka perihal upaya untuk melakukan sebuah proses pencegahan ataupun terkait dengan penanggulangan bagi kenakalan yang dilakukan oleh anak pada saat ini harusnya dengan sebuah pendekatan secara lebih khusus, perhatian secara lebih khusus, pertimbangan lebih khusus, bahkan terkait dengan pelayanan maupun perawatan secara lebih khusus lagi maupun terhadap perlindungan secara khusus lagi, dengan melakukan penyelenggaraan terkait dengan sistem peradilan pidana pada anak. Lebih secara khusus terkait dengan penanganan pada masalah yang berhubungan dengan kenakalan pada anak tersebut, oleh karena tindakan kenakalan yang dilakukan oleh anak yang merupakan bagian dari perbuatan konsep anti sosial yang akan menimbulkan keresahan bagi masyarakat, maupun timbulnya gejala umum yang akan diterima sebagai bagian dari fakta sosial yang ada. Disisi lain oleh karena anak yang telah melakukan tindakan kenakalan atas dasar perkembangan baik bagi fisik, mental yang ada pada dirinya maupun kehidupan sosialnya yang mempunyai posisi yang lemah jika disandingkan pada orang dewasa. Untuk melakuan perlindungan bagi anak yang nakal serta dari tindakan yang akan menghambat bagi perkembangan, maka perlu dibuatnya hukum kepidanaan serta hukum keacaraan pidana yang lebih khusus pula dalam hal ini..

Negara Indonesia merupakan negara hukum yang sebagaimana termuat di dalam konstitusinya pada aturan Undang-Undang Dasar Kenegara Repulik Indonesia pada Tahun 1945. Negara Indonesia sendiri sudah menjamin terhadap perlindungan kepada anak dalam beberapa aturan yang termuat, seperti pada : Undang-Undang Republik Indonesia Nomor ke 3 pada Tahun 1997 mengenai Pengadilan Pada Anak saat ini sudah diperbaharui dalam UndangUndang Nomor ke 11 pada Tahun 2012, UndangUndang Nomor ke 39 mengenai Hak Asasi Manusia serta UndangUndang Nomor ke 23 pada Tahun 2002 mengenai Perlindungan Anak sebagaimana telah mengalami perubahan pada Undang-Undang Nomor ke 35 pada Tahun 2014. Anak yang sebagai generasi sekaligus menjadi aset bangsa, anak yeng menjadi generasi muda penerus, menjadikan anak akan turut serta untuk berperan sangat strategis sebagai pendukung untuk meajukan suatu bangsa di masa yang akan datang. Pada konteks anak di Indonesia, anak disini merupakan penerus dari apa yang telah di cita-citakan perjuangan suatu bangsa. ${ }^{1}$ Undang-Undang Nomor ke 35 pada Tahun 2014 mengenai Perlindungan Anak berfungsi untuk menjamin akan terpenuhi apa yang menjadi hak anak sehingga anak dapat melanjutkan kehidupannya, tumbuh dan berkembangnya serta agar dapat berpartisipasi dengan optimal sesuai harkat dan martabat kemanusiaan yang melekat pada dirinya. Aturan Perundangan itu juga diberlakukan agar terciptanya perlindungan bagi anak dari tindakan kekerasan serta perlakuan tindakan diskriminasi terhadap anak, demi menciptakan anak Indonesia yang hebat, kualitas, amanah, tumbuh kemabng yang baik, pintar, dan mempunyai ahlak mulia serta memiliki kehidupan yang sejahtera. Terhadap anak yang telah berperan atau turut

${ }^{1}$ Maidin Gultom, Perlindungan Hukum Bagi Anak Pada Sistem Peradilan Anak yang ada di Indonesia, Refikatama, Bandung, 2009. Hal. 31. 
serta terkait pelanggaran hukum atau telah ikut dalam suatu perbuatan kriminal akan sangat didominasi oleh beberapa faktor yang mendasari motifnya tersebut antara lain : pergaulan bebas yang tidak terkontrol, pendidikan yang sangat rendah, teman pada saat bermainnya dan lainnya, oleh karena perbuatan pidana yang diperbuat oleh anak kebanyakan menjadi bagian dari proses untuk meniru maupun terpengaruh oleh tindakan negatif dari orang sekitarnya maupun orang dewasa dilingkungan sekitarnya.

Terkait dengan hukuman yang akan dibebankan kepada anak melalui sistem peradilan kepidanaan secara formal dengan cara mengikutsertakan dan menghukum anak masuk ke penjara hasilnya tidak menjadikan anak mempunyai sifat jera serta menjadi seorang pribadi yang akan menjadi lebih baik untuk mendorong proses tumbuh kembang di kemudian hari. Hukuman penjara justru akan berdampak pada anak yang semakin profesional dalam melakukan perbuatan pidana dikemudian hari. Kata-kata yang sering dipakai untuk mengatakan anak sebagai pelaku dari suatu perbuatan pidana yaitu juveenile delinqueency. Atau yang lazimnya dipakai sebagaimana termuat pada media massa yaitu tindakan kenakalan remaja atau sering juga disebut dengan kata kejahatan pada anak.

Perlidungan terhadap anak yang termuat pada sistem peradilan kepidanaan yang terkait erat ataupun dikatakan tidak dapat dipisahkan terhadap keadilan itu sendiri, oleh karena dalam sebuah sistem peradilan kepidanaan pada anak itu sendiri, selain termuat pada peraturan perundangan yang dijadikan sebuah landasan hukumnya maka harus termuat rasa keadilan serta keberpihakan kepada hak anak tersebut, juga harus ada unsur keadilan terkait dengan para aparat penegak hukum yang lebih khusus lagi kepada hakim yang dalam konteks implementasi penerapan sistem sanksi terkait pada anak tersebut, disini posisi hakim yang sangat berperan, karena dia menjadi tonggak terakhir dari sebuah proses peradilan dimana sebagai pemeriksa, pengadil, serta untuk memutus penerapan jenis sanksi apa yang akan dikenakan terkait anak yang telah terbukti melakukan perbuatan pidana. Jika keadilan dikaitkan pada perlindungan terhadap anak maka dalam keadilan akan tercermin sebuah perlindungan kepada anak dalam hala pencerminan keadilan, yang penerapannya terkait pada melindungi hak anak. Rasa keadilan merupakan sebuah penghargaan kepada setiap orang yang menurut harkat maupun martabatnya sebagai sosok pribadi serta dalam hubungam kepada segala sesuatu diluar dari dalam diri pribadinya. Untuk itu, yang menjadi solusi salah satu perihal penanganan perkara terkait perbuatan pidana kepada anak dengan melalui sebuah pendekatan restoratiive juctihce, penerapnnya melalui pengalihan (diversi pada asasnya). Restoratiive justiche itu sendiri adalah proses penyelesaian dilaksanakan di luar pola sebuah sistem pada peradilan pidana pada umumnya (Crimiinal Justiche Sistem) dengan mengikutsertakan pihak korban, pihak pelaku, maupun keluarga korban serta pelaku, dan lingkungan masyarakat sekitar dan juga pihak yang berkepentingan dalam perbuatan pidana tersebut yang terjadi untuk mencapai tujuan apa yang dinamakan dengan kesepakatan dan penyelesaian secara damai. ${ }^{2}$

Jika dilihat pada pendekatan ini didalam prakteknya akan mengalami perdebatan secara teoretis, namun jika pandangan ini berkembang lebih lanjut dan mempunyai dampak terkait dengan kebijakan hukum itu sendiri atau dengan legal policynya dan pada prakteknya dalam penegakan hukum itu sendiri yang berada di beberapa negara. Restoratiive justiche selain digunakan pada sistem peradilan anak, juga dianggap sebagai sebuah bentuk dari pemikiran yang baru sebagai solusi untuk digunakan dalam merespon berbagai kejahatan yang ada dan sekaligus menjawab ketidakpuasan pada kinerja dari sbuah sistem peradilan kepidanaan pada saat ini.

\section{METODE}

Terkait dengan penelitian yang dibuat oleh penulis ini dengan penggunaan tipe penelitian yang bersifat yuridis normatif disini terkait pada penelitian yang ditujukan kepada aturan norma yang termuat pada suatu aturan perundangan, sedangkan konsep pendekatan yang digunakan merupakan pendekatan dari perundangan serta pendekatan konsep melalui mengungkapan beberapa asas-asas hukum yang berkaitan dengan penerapan restorative justice pada peradilan pidana anak terkait pembaharuan hukum pidana di Indonesia, pembahasan dilakukan dengan cara deduktif untuk memperoleh kesimpulan yang bersifat kualitatif.

\section{HASIL DAN PEMBAHASAN}

\section{Tujuan Pidana Dan Pemidanaan Terhadap Pelaku Tindak Pidana}

Sebelum membahas jauh tentang restorative justice, terlebih dahulu harus di bahas dalam tulisan ini tentang tujuan kepidanaan serta apa yang dimaksud dengan pemidanaan bagi pelaku yang melakukan perbuatan pidana. Dapat dikatakan demikian, oleh karena mengenai salah satu bagian yang tidak dapat dipisahkan dalam ketentuan hukum kepidanaan yang merupakan bagian dari hukum pidana itu sendiri. Bukan mengenai ketentuan hukum kepidanaan dari suatu peraturan yang hanya mengenai norma tanpa diikuti oleh suatu ancaman ketentuan pidana saja. Ketentuan pidana yang dijatuhkan kepada mereka yang dianggap bermasalah, yang merupakan bagian dari sikap penderitaan yang harus dilalui, meskipun seperti itu, sanksi mengenai ketentuan kepidanaan bukanlah semata-mata untuk 
bertujuan memberikan rasa penderitaan. ${ }^{3}$ Mengenai ketentuan ke pidanaan yang pada hakekatnya merupakan bagian dari alat untuk mendapatkan tujuan serta bagaimana cara untuk merumuskan suatu tujuan tersebut yang termuat dalam konsep maupun materi suatu aturan perundangan yang pada pembentuknya ingin dilakukan penegakan dengan cara memasukkan unsur pidananya. Selain mengenai penegakan di dalamnya juga mengenai ketentuan dengan tujuan dari apa yang dicapai dalam pemidanaan serta syarat dari pemidanaan itu sendiri. Tujuan dari pemidanaan itu sendiri terdapat ketentuan akan melindungi masyarakat serta perlindungan hukum maupun mengenai pembinaan terhadap pelakunya. Seperti apa yang di ungkapkan oleh Barda Nawawi Arief mengatakan bahwa, mengenai ketentuan pidana pada umumnhya hanya sebagai alat untuk mencapai dari apa yang telah termuat dalam tujuan yang bertitik bertolak pada keseimbangan mengenai dua sasaran pokok yang ingin dicapai yaitu merupakan perlindungan masyarakat serta mengenai perlindungan atau pembinaan terhadap individu maupun pelaku dari orang yang melakukan perbuatan pidana. Bertolak dari ketentuan mengenai keseimbangan tersebut, yang menjadi syarat dari suatu pemidanaan berdasarkan dari sebuah konsep juga akan bertolak dari pemikiran mengenai keseimbangan monodualistik diantara dua kepentingan yaitu pada masyarakat maupun kepentingan individu, serta faktor obyektif maupun faktor subyektif. ${ }^{4}$

Jadi mengenai ketentuan pidana disini merupakan bagian dari nestapa yang akan dikenakan untuk orang yang telah melanggar dari apa yang termuat pada ketentuan perundangan. Pidana dikenakan secara sengaja oleh negara bagi terpidana biar dapat merasakan apa yang menjadi nestapa. Penderitaan dari ketentuan kepidanaan itu sendiri adalah sebuah tindakan penebusan dosa dari si pembuat atas apa yang telah dilakukannya. Dengan penebusan dosa tersebut, diharapkan pada kesalahan yang telah dilakukan sebelumnya akan dapat timbulnya keseimbangan pada tatanan nilai pada diri si pembuat tindak pidana tersebut. Penebusan diri merupakan bagian dari kebutuhan fundamental serta sifat moral kita. ${ }^{5}$

Disisi lain pada ketentuan pidana yang merupakan bagian dari suatu reaksi terhadap delik maupun berwujud pada suatu nestapa yang dengan di sengaja dijatuhkan oleh negara kepada pelanggaran pidana itu. ${ }^{6}$ Nestapa yang dimaksud disini dijatuhkan kepada si pembuat delik bukan merupakan suatu tujuan terakhir yang ingin dicitakan oleh masyarakat, tetapi disini nestapa bukan hanya merupakan suatu tujuan yang terdekat. Ketentuan mengenai hukum kepidanaan pada tujuannya untuk mencapai hal tersebut tidak semata-mata dengan cara penjatuhan hukum pidana saja, tetapi dengan jalan pengunaan dari tindakan-tindakan. Sedangkan apa yang diungkapkan oleh Roeslan Saleh ${ }^{7}$ mengenai tindakan apa yang dapat dipandang dari suatu sanksi, tetapi bukan bersifat pada pembalasan, serta yang diarahkan pada semata-mata hanya prevensi khusus, maupun tindakan tersebut ditujukan untuk menjaga dari keamanaan masyarakat dari ancaman-ancaman bahaya.

Sedangkan apa yang dikatakan Simon, pidana itu sendiri merupakan suatu penderitaan sesuai dengan apa yang diamanatkan oleh perundangan pidana yang dikaitkan pada pelanggaran mengenai suatu aturan norma, yang apabila pada putusan hakim sudah diputuskan bagi orang tersebut sudah bersalah. Disisi lain mengenai pidana itu menurut Van Hamel adalah :

"merupakan suatu penderitaan yang secara bersifat khusus, yang sudah diputuskan dari kekuasaan yang memiliki kewenangan untuk memutuskan ketentuan kepidanaan berdasarkan nama negara yang disni sebagai penanggungjawab atas keterlibatan ketentuan hukum umum terhadap orang yang melakukan pelanggaran tersebut, yaitu hanya seolah-olah orang tersebut telah melanggar ketentuan peraturan hukum yang merupakan keharusan ditegakkan oleh negara." 8

Persoalan mengenai pemidanaan bukanlah merupakan suatu proses biasa untuk menghukum seseorang ke dalam sebuah penjara. Pemidanaan pada umumnya merupakan gambaran dari sistem mengenai moral, pada nilai kemanusiaan serta terhadap pandangan filosofis dari masyarakat manusia yang berada di zaman tertentu, sehingga mengenai permasalahan tersebut terhadap sistem pemidanaan paling tidak harus terdapat tiga pandangan yaitu unsur filosofis, sosiologis maupun kriminologis. Pemidanaan itu sendiri merupakan bagian terpenting dalam ketentuan hukum kepidanaan, karena merupakan akhir dari seluruh proses untuk pertanggungjawaban bagi seseorang atas kesalahannya yang telah melakukan perbuatan pidana. Dengan demikian hukum kepidanaan tanpa pemidanaan itu menyebutkan bahwa orang yang telah bersalah tanpa adanya akibat yang pasti ats kesalahan yang telah diperbuatnya. Dengan demikian pada konsep mengenai kesalahan dan memiliki pengaruh yang sangat signifikan bagi pengenaan

${ }^{3}$ Niniek Suparni, Eksistensi Terhadap Kepidanaan Dalam Penerapan Sebuah Denda Terkait Sistem Kepidanaan dan Pemidanaan, Sinar Grafiika, Jakarta, 2003, hal. 1-2.

${ }^{4}$ Barda Nawawi Arief, Kebijakan Perihal Hukum Kepidanaan, Sinar Grafika, Jakarta, 2003, hal. 88.

5 Barda Nawawi Arief, Politik Terhadap Legislatif Mengenai Penanggulangan Terhadap Suatu Kejahatan Terhadap Penggunaan Pidana Penjara, Badan Kencana Utama, Semarang, 2004., hal. 159.

${ }^{6}$ Roeslan Saleh, Hukum Kepidanaan yang Merupakan sebuah Alat Untuk Mengkonfrontasikan Manusia, Agung Grafika, Jakarta, 2005, hal. 5.

${ }^{7}$ Roeslan Saleh, Stelsel Dkaitkan Terhadap Pola Kepidanaan Indonesia, Tunas Baru, Jakarta, 2004, hal. 9.

${ }^{8}$ Loc. Cit. 
kepidanaan serta pada proses penerapannya. Jika kesalahan disini dapat dipahami sebagai dikenakannya celaan, jadi di sini pemidanaan adalah perwujudan atas celaan tersebut. ${ }^{9}$

Namun demikian sebagaimana yang termuat pada hukum pidana juga harus dipikirkan terhadap apa yang menjadi tujuan serta pedoman pada pemidanaan. Seperti yang diketahui pada rumusan mengenai tujuan maupun pedoman pemidanaan tersebut dalam sebuah aturan khusus menempati posisi sentral yang bertujuan memberikan arah maupun pegangan yang jelas terhadap hakim dalam penjatuhan pidana. Hal ini sesuai yang pada hakekat atas perundangan itu sendiri yang sebenarnya adalah bagian dari sistem hukum yang memiliki tujuan. ${ }^{10}$ Selain itu dengan adanya tujuan serta pedoman terhadap pemidanaan ditujukan sebagai fungsi dari pengendalian ataupun kontrol, sekaigusdan juga memberikan landasan dasar filosofis, maupun rasionalitas serta motivasi atas pemidanaan yang terukur dan terarah. ${ }^{11}$

Ada terdapat berapa tujuan yang akan hendak dicapai atas pemidanaan, seperti apa yang disampaikan oleh G. Peter Hoefnagels sebagaimana yang telah dikutip oleh Muladi dan Barda Nawawi Arief menyebutkan tujuan pidana itu merupakan :

1. Untuk penyelesaian dari sebuah konflik \{confliict resolution\}.

2. Untuk mempengaruhi terhadap pelanggar-pelanggar maupun terhadap orang lain kearah perbuatan yang kurang lebih sesuai dengan apa yang diamantkan oleh hukum \{influeencing ofenders and possibility other than ofenders toward more or less law-confor behavior .

Sementara menurut Roeslan Saleh mengatakan bahwa pada hakekatnya terdapat 2 (dua) yang menjadi poros untuk menentukan garis dasar hukum pidana, yaitu : ${ }^{12}$

1. Dari segi prevensi, dimana terhadap ketentuan hukum kepidanaan merupakan hukum sanksi, agar dapat mempertahankan terhadap kelestarian hidup bersama terkait pada pencegahan kejahatan.

2. Dari segi pembalasan, dimana hukum adalah penentuan atas hukum, yang merupakan koreksi dari dan reaksi kepada suatu yang bersifat non hukum.

Dengan demikian pada hakekat atas ketentuan kepidanaan disini merupakan bagian terhadap suatu perlindungan bagi masyarakat maupun atas pembalasan terhadap perbuatan yang non hukum. Di lain pihak seperti apa yang diungkapkan oleh Roeslan Saleh terhadap pidana yang mengandung hal-hal lain, yang akan membawa kerukunan maupun pidana merupakan suatu proses terhadap pendidikan untuk membuat agar seseorang dapat diterima kembali di lingkungan masyarakat.

Terhadap pada pedoman pemidanaan tersebut, ada beberapa pedoman terkait pemidanaan, yaitu $:^{13}$

1. Pada pedoman yang bersifat umum yang akan secara langsung memberi arah terhadap hakim atas apa yang seharusnya menjadi pertimbangan di dalam memutus pemidanaan.

2. Pada pedoman yang bersifat khusus akan memberikan arah kepada hakim dalam pemilihan serta terhadap penjatuhan jenis pada pidana tertentu.

3. Pada pedoman bagi hakim terkait dengan penerapan sistem yang termuat dalam perumusan bagi ancaman pidana yang akan dipakai untuk merumuskan delik.

Namun demikian, pada kenyataannya ada fakta yang mengataakan terdapat sebuah kesenjangan antara harapan maupun kenyataan tersebut. Disini dapat dilihat masih tingginya angka residivis atas kejahatan tersebut, dan juga banyak kejahatan yang mengakibatkan viktimisasi bagi narapidana yang melakukan kejahatan di sebuah lingkaran terkait dengan sistem peradilan pidana. Pelaku dari kejahatan itu sendiri yang dikenakan hukuman pidana di Kelembagaan Pemasyarakatan yang semestinya akan tersadar terhadap semua kesalahan yang sudah dilakukannya serta berharap akan kembali menjadi orang baik yang hidup di tengah-tengah masyarakat. Akan tetapi pada realitanya sering kali pelaku masih dianggap tidak akan bisa kembali untuk menjadi orang baik, sehingga tidaklah diragukan lagi apabila seperti apa yang diungkapkan bahwa penjara merupakan sekolah kejahatan.

Timbulnya sebuah model penghukuman secara restoratif disebabkan kepada sistem peradilan pidana serta pemidanaan yang saat ini berlaku mengakibatkan berbagai masalah. Di daalam sebuah sistem penjara yang ada saat ini dengan tujuan pemberian hukuman merupakan penjeraan, ataupun atas pembalasan dendam maupun sebagai pemberian penderitaan atas sebuah konsekuensi yang diberikan atas perbuatan itu. Indikator penghukuman tergantung

${ }^{9}$ Chairul Huda, Bermula Pada Tidak Ada sebuah Pidana Dengan Tidak Ada Kesalahan Menuju Kepada Asas Tiada Pertanggungjawaban Terhadap Pidana Tidak Ada Kesalahan, Sinar Grafika, Jakarta, 2004., hal. 124.

${ }^{10}$ Barda Nawawi Arie, Kebijakan Hukum Pidana, Op. Cit. hal. 136.

11 Loc. Cit.

12 Roeslan Saleh,Pandangan Terhadap Hukuman Kepidanaan, Sinar Baru, Jakarta, 2007, hal. 25.

13 Ibid. hal. 137. 
pada sebatasmana seorang narapidana akan tunduk kepada sebuah peraturan penjara. Jadi, dapat dikatakan sebuah pendekatan yang lebih kepada keamanan. Selain itu, penjara juga akan berdampak pada keluarga dari seorang narapidana, sedangkan sistem yang digunakan saat ini dinilai tidak memberikan keluasan maupun penyembuhan kepada pihak korban. Apabila proses hukumnya akan menggunakan waktu yang cukup lama. Sebaliknya, terhadap pemidanaan restoratif yang melibatkan korban, keluarga maupun pihak-pihak lain perihal terkait dengan penyelesaian masalah. Disisi lain, untuk mejadikan seorang pelaku tindak pidana akan bertanggungjawab atas kerugian yang diakibatkan atas perbuatan itu. Kepada korban yang ditekankan mengenai pemulihan kerugian aset yang dimilikinya, derita fisik yang dialaminya, terhadap keamanan dirinya, kepada harkat maupun kepuasan atau rasa adil.

Restorative justice akan meletakkan terkait dengan nilai yang lebih tinggi lagi dalam keterkaitan secara langsung yang berasal dari para pihak. Disisi lain korban mampu agar memberikan unsur kontrol, disisi lain kepada pelaku agar didorong dalam rangka menanggung beban tanggungjawab sebagai sebuah langkah untuk memperbaiki kesalahan-kesalahan yang diakibatkan pada perbuatan kejahatan serta dalam pembangunan sebuah sistem nilai sosial. Keterkaitan pada komunitas secara aktif akan mempererat komunikasi dengan sendiri serta diharapkan agar dapat mengikat komunitas perihal terkait dengan nilai-nilai untuk menghormati maupun rasa saling mengasihi antar satu dengan lainnya. Sehingga peranan yang ada pada pemerintah dapat berkurang dan memonopoli pada proses peradilan yang ada. Restoratiive justice itu sendiri memerlukan usaha yang kooperatif sebagai sebuah kondisi tertentu dimana seorang korban maupun pelaku agar dapat merekonsiliasikan terkait dengan konflik mereka serta akan memperbaiki luka-luka yang dialami oleh mereka.

\section{Konsep Restorative justice}

Apa yang dinamakan dengan konsep restorative justice itu sendiri sebenarnya sudah muncul cukup lama, kurang lebih berawal dua puluh tahun silam yang lalu sebagai bagian alternatif penyelesaian terhadap perkara kepidanaan, teruntuk pada perkara anak dengan alasan banyak pertimbangan. Seperti telah apa yang diungkapkan oleh John Braitewaite justiice serta welffare model selanjutnya antara retribution dan rehabitation. Di Negara lain seperti Amerika Utara, Australia maupun sebagian negara di Eropa keadilan restoratif ini sudah ada digunakan pada semua tahap proses peradilan pidana pada umumnya yaitu pada tahap dimulainya penyidikan serta penuntutan, pada tahap adjudikasi maupun tahap eksekusi ke dalam penjara. Pada perkembanga saat itu, pertumbuhan serta penyebaran keadilan restoratif ini diduga telah memperoleh dukungan dari organisasi perserikatan bangsa-bangsa. Dimana dalam kongres ke Lima Tahunan tepatnya ke-5 di Jenewa pada tahun 1975, PBB telah menaruh perhatian kepada sistem ganti rugi terhadap korban yang diakibatkan oleh kejahatan, hal ini menjadi alternatif terhadap peradilan pidana retributif.

Konsep faktual dari adanya praktek keadilan restoratif ini bermulal atas praktek pemeliharaan terhadap perdamaian yang dipilih oleh suku bangsa Maori yang merupakan penduduk asli berasal dari suku di Selandia Baru. Apabila muncul konflik, praktek restoratif akan diterapkan bagi dari pihak pelaku, pihak korban maupun para steakholders. Pada intinya restoratiive justiice mengedepankan arti dari pertemuan diantara kedua belah pihak yang berkonflik dalam kejahatan serta periode sesudahnya. Seperti dengan apa yang telah diungkapkan oleh Achmad Ali yang mengikuti pendapat dari Howard Zher yang merupakan seorang perintis dari keadilan restoratif di negara Amerika Serikat, mengartikan restoratiive justihce merupakan "suatu proses yang mengkaitkan antara kedua belah pihak yang berkepentingan atas sebuah pelanggaran khusus maupun secara bersama untuk mengidentifikasikan dampak kerugian yang ditimbulkan serta pemenuhan atas kewajiban maupun terhadap kebutuhan serta penempatan perubahan sebagai bagian dari hak yang harus diperolehnya. Atas beberapa pendapat tersebut, untuk mengupayakan penyelesaian konflik serta dalam rangka penyembuhan diantara pelaku maupun korban dengan caranya yaitu mempertemukan atau menghadirkan pelaku kedalam satu forum dengan korbannya atau keluarganya untuk menciptakan rasa empati di antara kedua belah pihak.

Dengan begitu terhadap penyelesaian konflik yang dimunculkan bukan untuk menampilkan semata-mata kesalahan yang dilakukan pelanggar kemudian untuk penjatuhan sanksi pidana kepadanya, melainkan peran aktif diantara kedua belah pihak yang sedang berkonflik dengan cara mediasi ataupun kompensasi bagi kerugian material serta immaterial yang berwujud restitusi ataupun kompensasi dan juga terhadap pemulihan atas keharmonisan dari hubungan kemanusiaan diantara kedua belah para pihak. Mudzakin seperti apa yang telah dikutipnya dari Van Ness yang mengungkapkan bahwa restoratiive justihce atau keadilan restoratif diartikan dengan beberapa pandangan, berupa :

1. Kejahatan itu merupakan bagian dari konflik individu yang berakibat timbulnya kerugian terhada korban, baik bagi masyarakat maupun dari pelaku itu sendiri.

2. Tujuan akhir yang harus harus didapatkan atas proses peradilan kepidanaan ini merupakan dengan cara rekonsiliasi di antara kedua belah pihak sambil saling memperbaiki atas kerugian yang diakibatkan dari kejahatan tersebut. 
3. Pada proses peradilan kepidanaan itu sendiri harus memfasilitasi peran partisipasi aktif terhadap korbannya, pelangganyar serta masyarakat dilingkungan sekitarnya, tidak hanya pada peradilan pidana dimonopoli oleh negara dengan cara mengesampingkan lainnya.

Dari beberapa pendapat ahli di atas, sudah jelas mengatakan kepada keadilan restoratif merupakan sebuah konsep atas dasar pemikiran yang akan merespon pengembangan di dalam sebuah sistem pada peradilan pidana dengan mengutamakan pada keterlibatannya masyarakat maupun kepada korbannya terhadap sebuah penyelesaian perkara kepidanaan yang telah ada sebelumnya. Perdebatan seperti ini terkait dengan tahapan proses dari penegakan hukum kepidanaan pada tingkat penyidikan, terutama pada proses penegakkan hukum terhadap perkara tertentu di Indonesia disesuaikan dengan berat ringannya atas pidana yang dilakukannya, besar kecilnya kerugian terkait dengan dampak yang ditimbulkan, kondisi dari latar belakang serta motif pelaku itu sendiri dilihat keadaan sosiologis masyarakat setempat. Bahwa restoratiive justiive ini sendiri sudah diakui secara internasional sebagai wujud dari penyelesaian terhadap perkara pidana. Konsep ini akan sesuai dengan kondisi hukum yang berkembang di dalam masyarakat.

Di Indonesia sendiri sebenarnya konsep dari restoratiive justiche sudah lama diterapkan oleh masyarakat di Indonesia, seperti pada lingkungan masyarakat di daerah Papua, Kalimantan, Toraja, Minang, Bali, Kabau, Jawa Tengah serta masyarakat lainnya yang masih menerapkan kuat nilai kebudayaa. Jika terjadi munculnya suatu perbuatan pidana yang dilakukan oleh seseorang. Maka terhadap praktek dari penyelesaian yang dilakukan dengan cara pertemuan atau musyawarah untuk mencapai kemufakatan yang akan dihadiri oleh tokoh pemuka adat masyarakat, maupun pelaku, korban serta kedua orang tua pelaku untuk terwujudnya kesepakatan dalam rangka perbaikan atas kesalahan yang sudah terjadi. Hal ini pada hakikatnya merupakan nilai serta ciri falsafah bangsa Indonesia termuat dalam sila keempat Pancasila, yaitu musyawarah untuk mencapai kemufakatan. Dengan demikian, konsep restoratiive justiche sebenarnya bukan hal baru dikalangan masyarakat Indonesia. Dalam musyawarah untuk mencapai kemufakatan ini dengan tujuan perdamaian, yang akan membuat antara pelaku serta korban tidak ada lagi rasa dendam diantara kedua belah pihak maupun terhadap kondisi korban yang dapat dipulihkan. Musyawarah untuk mencapai kemufakatan ini dalam konsep restoratiive justiche bisa diterapkan dengan cara seperti : mediasi, pembayaran ganti rugi atau restitusi, adapun dengan cara lain yang sudah disepakati diantara korban ataupun dari keluarga korban dengan pelakunya.

\section{Konsep Restorative Justice Pada Sistem Peradilan Keidanaan Anak Di Indonesia}

Membahas tentang anak jika dikaiitkan dengan macam ragam pengertian dan maknanya mempunyai perbedaan serta karakteristik terhadap orang dewasa, hal ini adalah bagian dari titik tolak dalam melihat sebuah hak serta kewajiban bagi seorang anak hingga akan berdampak pada kedudukan didepan hukum. Dalam pengaturan mengenai konsep pertimbangan yang termuat pada Undang-Undang Nomor ke 11 pada Tahun 2012 mengenai Sistem Peradilan kepidanaan pada Anak juga menyatakan bahwa anak adalah sebuah amanah serta karunia yang diberikan oleh Tuhan Yang Maha Esa dan mempunyai harkat serta martabat sebagai seorang manusia yang seutuhnya. Untuk melindungi harkat serta martabatnya, seorang anak berhak mempunyai pelindungan secara khusus, yang paling utama pada pelindungan hukum serta sistem peradilan anak. Sedangkan apa yang dikatakan oleh Retnowulan Sutianto, terhadap perlindungan anak adalah bagian dari sebuah Pembangunan Nasional yang ada. Perlindungan terhadap anak yaitu melindungi diri pada manusia, dan membangun manusia untuk menjadi seutuh mungkin. Dapat terlihat pada hakekat pembangunan nasional adalah pembangunan manusia Indonesia seutuhnya memiliki budi luhur. Mengabaikan masalah terhadap perlindungan anak disini bahwa tidak akan memantapkan sebuah pembangunan nasional yang baik. Dampak dari tidak adanya perlindungan kepada anak akan mengakibatkan berbagai persoalan sosial yang akan mengganggu terhadap penegakan hukum di negara, serta ketertiban, baik keamanan, maupun pembangunan nasional itu sendiri. ${ }^{14}$

Indonesia sebagai Negara atas Pihak terhadap Konvensi Hak-Hak Anak (Conventiion on thee Rightss of the Childern) disini mengatur mengenai perlindungan hukum bagi anak, serta berkewajiban untuk memberikan sebuah perlindungan secara khusus kepada anak-anak saat memiliki masalah terhadap hukum. Salah satu yang menjadi bentuk terhadap sebuah perlindungan bagi anak oleh negara dapat diwujudkan melalui sebuah sistem pada peradilan kepidanaan secara khusus terhadap anak yang akan berhadapan dengan hukum itu sendiri. Hal ini diperjelas dalam Uniteed Natioals of the Standartd Minimum Rules For the Administration of the Juvenile Justice, disini menyatakan bahwa peradilan anak merupakan : sebuah sistem peradilan kepidanaan terhadap anak atau remaja yang akan memperioritaskan terhadap kesejahteraan remaja serta akan memastikan bahwa terhadap sebuah reaksi maupun terkait dengan pelanggaran hukum yang dilakukan pada saat usia remaja akan selalu sepadan dengan kondisi yang baik pada pelanggaran hukumnya ataupun terhadapn pelanggaran hukum.

${ }^{14}$ Romli Atmasasmita, Sistem Terkait Peradilan Anak Indonesia, Mandar Maju, Bandung, 2007, hal. 166. 
Dalam Pasal ke 1 butir ke (6) Perundangan Nomor ke 11 Pada Tahun 2012 Mengenai sebuah Sistem Peradilan Kepidanaan pada Anak menyebutkan, Bahwa pada Keadilan restoratif merupakan sebuah konsep penyelesaian perkara perbuatan pidana dengan cara mengikutsertakan pihak pelaku, pihak korban, serta keluarga pelaku maupun korbannya, dan juga kepada para pihak lain yang terkait untuk secara bersama untuk mencari jalan penyelesaian konflik yang adil dengan cara penekanan pada pemulihan kembali kepada keadaan semula, dan bukan merupakan sebuah unsur pembalasan.

Sistem Peradilan Kepidanaan Pada Anak wajib memperioritaskan kepada konsep pendekatan Keadilan Restoratif. Sistem Peradilan Kepidana Anak ini, yaitu:

1. Pada proses tindakan penyidikan serta sebuah penuntutan pidana pada Anak yang dikerjakaan sesuai dengan pola ketentuan peraturan perundangan, kecuali jika ditentukan lain dalam aturan ini;

2. Pada persidangan Anak yang dilaksanakan oleh pengadilan di lingkungan pada tatanan peradilan umumnya; dan

3. Pada pembinaan, pembimbingan, serta pengawasan, maupun atas pendampingan selama proses pelaksanaan kepidanaan ataupun bagian dari tindakan serta setelah menjalani prose pemidanaan atau sebuah tindakan.

Dalam Sistem Peradilan Pidana Anak sebagaimana dimaksud pada ayat (2) huruf a dan huruf b wajib diupayakan Diversi. Diversi adalah pengalihan penyelesaian perkara Anak dari proses peradilan pidana ke proses di luar peradilan pidana.

Undang-Undang Nomor 11 Tahun 2012 telah mengedepankan pendekatan restorative justice dan proses diversi sebagai upaya penyelesaian tindak pidana yang dilakukan oleh anak, sehingga penerapan restorative justice akan menawarkan jawaban atas isu-isu penting dalam penyelesaian perkara pidana, yaitu: pertama, kritik terhadap sistem peradilan pidana yang tidak memberikan kesempatan khususnya bagi korban (criminal justice system that disempowers individu); kedua, menghilangkan konflik khususnya antara pelaku dengan korban dan masyarakat (taking away the conflict from them); ketiga, fakta bahwa perasaan ketidakberdayaan yang dialami sebagai akibat dari tindak pidana harus di atasi untuk mencapai perbaikan (in orderto achievereparation).

Penerapan prinsip restorative justice dan proses diversi sebagai upaya penyelesaian tindak pidana yang dilakukan oleh anak walaupun secara yuridis formil telah diatur secara jelas dan tegas di dalam Undang-Undang Nomor 11 Tahun 2012, namun secara formil pula muncul permasalahan terkait dengan waktu berlakunya undangundang tersebut yang pada Pasal 108 disebutkan: "Undang-Undang ini mulai berlaku setelah 2 (dua) tahun terhitung sejak tanggal diundangkan" yang berarti undang-undang tersebut baru berlaku pada bulan Juli tahun 2014, hal ini tentu akan memunculkan permasalahan bagi penyelesaian tindak pidana yang melibatkan anak, di samping itu kesiapan bagi seluruh aparatur penegak hukum, pemahaman masyarakat, dan sarana serta pra-sarana menjadi faktor pendukung yang tidak dapat dikesampingkan dalam menunjang berlakunya undang-undang tersebut. Ketika faktor pendukung tersebut tidak memadai maka akan menimbulkan permasalahan kembali dan tentunya akan berimbas bagi anak baik langsung maupun tidak langsung.

Penerapan keadilan pada konsep restoratif merupakan penyelesaian sebuah perbuatan pidana yang diperbuat oleh anak-anak merupakan perintah secara sah, jelas maupun secara tegas berdasarkan Perundangan Nomor ke 11 Pada Tahun 2012 mengenai Sistem Peradilan Kepidanaan Pada Anak. Dalam pertimbangannya peraturan ini antara lain dikatakan, anak adalah sebuah amanah serta karunia Tuhan Yang Maha Esa serta mempunyai harkat maupun martabat sebagai manusia yang seutuhnya. Untuk menjaga harkat maupun martabatnya, serta anak tersebut berhak memperoleh pelindungan secara khusus, terutama atas pelindungan terkait denngan hukum dalam sebuah sistem peradilan.

\section{Konsep Restoratiive Justiche Dalam Pembaharuan Hukum Kepidanaan Di Indonesia}

Terkait dengan pembaharuan hukum kepidanaan di sisi materiilnya yang berbentuk sebuah Rancangan Perundang-Undangan Kitab Undang-Undang Hukum Kepidanaan atau RUUKUHP, yang menjadikan sebuah upaya menciptakan sebuah cita-cita negara terkait dibidang hukum. Sehingga RUU KUHP menjadikan sebuah perwujudan baik secara kepribadian dari sebuah bangsa Indonesia yang tidak hanya mengutamakan suatu kepentingan secara individual maupun memperioritaskan kepentingan sebuah negara. Terkait dengan pembaharuan hukum kepidanaan dengan tujuan perbaikan atas hukum yang ada merupakan dengan cara penggantian hukum yang ada terkait hukum yang dengan harpan akan menjadi lebih baik. Sehingga RUU KUHP bukan semata-mata untuk menciptakan sebuah perubahan yang seperlunya yang akan mengganti sebuah baju kolonial menjadikan sebuah kemasan nasional, melainkan berwujud dari suatu kemerdekaan maupun kedaulatan sebuah bangsa yang senyatanya. Bahkan terkait dengan pembaharuan hukum untuk menentukan sebuah arah dalam membentuk sebuah watak bangsa, terkait dengan keadaan yang riil menuju kondisi ideal sepenuhnya, sehingga RUU KUHP merupakan bagian dari alat transformasi sosial dan budaya masyarakat secara terprogram.

Hukum pidana merupakan salah satu bagian independen dari hukum publik yang merupakan salah satu instrumen hukum yang sangan penting eksistensinya sejak jaman dahulu. Eksistensi hukum pidana sangat penting 
dalam menjamin keamanan masyarakat dari ancaman tindak pidana, menjaga stabilitas negara dan merupakan lembaga moral yang berperan merehabilitasi para pelaku tindak pidana. Sehingga hukum pidana terus berkembang sesuai dengan tuntutan perkembangan masyarakat. Salah satu perkembangan tersebut adalah munculnya ide penyelesaian konflik yang tidak hanya terfokus pada proses hukum di pengadilan, akan tetapi diselesaikan oleh para pihak yang berkonflik dengan cara memulihkan keadaan yang ada. Prinsip inilah kemudian dikenal dengan restorative justice yang diperkenalkan dalam RUU KUHP melalui sejumlah ketentuan dalam Pasal 2, Pasal 12, Pasal 54 dan Pasal 55, adanya mediasi dalam pasal 145 huruf d, serta diversi terhadap anak dalam peradilan pidana. Munculnya konsep ini terutama untuk memberikan keseimbangan perhatian antara steakholders hukum pidana yaitu pelaku, korban, masyarakat dan negara. Keseimbangan tersebut juga terlihat dalam pengaturan tentang pidana dengan pengaturan tentang tindakan dan dimungkinkan sanksi gabungan antara pidana dan tindakan mengingat beragamnya masalah kejahatan, serta kesadaran tentang pentingnya terapi yang tepat terhadap korban kejahatan.

Sebenarnya konsep restorative justice merupakan wujud dari hukum adat yang sudah ada sejak dahulu berkembang dalam masyarakat Indonesia. Sehingga diakuinya hukum adat dalam RUU KUHP bertujuan untuk memenuhi rasa keadilan yang hidup dalam masyarakat dengan memulihkan keadaan yang telah rusak atau proses dimana pihak-pihak berkepentingan memecahkan secara bersama cara mencapai kesepakatan setelah terjadi suatu tindak pidana termasuk implikasinya di kemudian hari. Dengan demikian, restorative justice dalam penanganan tindak pidana tidak hanya dilihat dari kacamata hukum saja, tetapi juga dikaitkan dengan aspek-aspek moral, sosial, ekonomi, agama dan adat istiadat lokal serta berbagai pertimbangan lainnya.

Dalam acara pidana konvensional apabila telah terjadi perdamaian antara korban dan pelaku, tetapi hal tersebut tidak bisa mempengaruhi kewenangan penegak hukum untuk meneruskan perkara tersebut ke pengadilan yang nantinya akan berujung pada pemidanaan, karena perdamaian tidak menghapuskan sifat pidananya perbuatan. Proses pidana yang memakan waktu lama serta tidak memberikan kepastian bagi pelaku maupun korban tentu tidak serta merta memenuhi ataupun memulihkan hubungan anatar korban dan pelaku, tetapi konsep restorative justice ini menawarkan proses pemulihan yang melibatkan pelaku dan korban secara langsung dalam penyelesaian masalahnya. Proses pidana konvensional ini hanya menjadikan korban nantinya sebagai saksi dalam tingkat persidangan yang tidak banyak mempengaruhi putusan pemidanaan.

Selain itu, terkait dengan perkembangan hukum kepidanaan hingga era ini juga adanya konsep disebut dengan mediasi penal. Dalam prakteknya pada hukum kepidanaan, mediasi penal juga dianggap sebagai wadah untuk turunan dari konsep restoratiive justiche, oleh karena tidak perlu melaksanakan sebuah hukum kepidanaan lewat jalur pengadilan. Hal ini mengakibatkan penyelesaian perkara diluar pengadilan atau secara ARD biasanya digunakan dalam sebuah perkara keperdataan, tetapi tidak untuk perkara kepidanaan. Oleh karena terkait dengan perkara pidana tidak dapat dilaksanakan di luar dari ruang sidang pengadilan, tetapi pada prakteknya untuk hal tertentu dimungkinkan dilaksanakan, bahkan boleh jadi penyelesaian di luar pengadilan menjadi hal akan sifat keidealannya.

Dalam masa di era perkembangannya terkait dengan pembaharuan hukum pidana di berbagai negara ada kemungkinan kuat atas penerapan konsep mediasi penal sebagai salah satu jalan terkait dengan penyelesaian masalah di bidang hukum kepidanaan. Semakin banyak terhadap penyelesaian konflik hukum bagian kepidanaan yang sering digunakan oleh masyarakat mengakibatkan tuntutan untuk mempositifkan bentuk dari sebuah penyelesaian perkara di luar dari pengadilan yang semakin kuat. Restoratiive justiche disni digunakan untuk menekan pada hak asasi manusia seseorang serta akan kebutuhan untuk pengembalian dampak dari sebuah rasa yang mengakibatkan ketidakadilan sosial baik dalam cara yang sangat simple memberikan keapda pelaku keadilan terhadap sebuah keadilan formal korban untuk tidak mendapatkan keadilan apapun. Kemudian konsep restoratiive justiche ini juga mengupayakan agar merestor keamanan pada diri korban, atas penghormatan pribadi orang tersebut, dan juga kepada martabat dan yang lebih penting merupakan sence of control.

\section{SIMPULAN}

Restoratiive justiche ini perlu dijadikan pertimbangan perihal terkait pembaharuan hukum pidana karena Restorative justice ini lebih mengutamakan kepada keadilan yang bersifat restorative serta meberikan peran aktif kepada pelaku, korban serta masyarakat untuk menyelesaiakan konflik hukum pidana diluar pengadilan dengan menggunakan cara musyawarah mufakat untuk menemukan kesepakatan dalam menyelesaikan permaslahan.

Restorative justice ini sudah dikenal lama di Indonesia yaitu melalui masyarakat hukum adat karena akan berdampak keapda asas kemanfaatan dengan sifat kebersamaan serta untuk mengabaikan sebuah dampak yang buruk terhadap kepidanaan dalam kepenjaraan maupun bagi pemulihan hak atas korbannya.

Konsep restoratiive justiche ini jika dimasukkan dalam sebuah sistem pada peradilan kepidanaan anak dianggap secara baik terhadap penerapnnya, karena restoratiive justiche berguna dalam rangka menghindarkan terhadap anak terhadap sistem pemidanaan dan akan diganti pada pola pembimbingan kepada anak tersebut. Indonesia sendiri sudah mempraktekkan sebuah konsep dari restoratiive justiche melalui pada sistem diversi yang termuat dalam aturan Perundang-Undang Nomor ke 11 pada Tahun 2012 mengenai Sistem Peradilan keidanaan terkait Anak. 
Ryan Aditama dan Novia Yolanda, Penerapan Restorative Justice pada Peradilan Pidana Anak Terkait Pembaharuan Hukum Pidana di Indonesia

\section{DAFTAR PUSTAKA}

\section{Buku}

Arief, Barda Nawawi, Kebijakan Perihal Hukum Kepidanaan, Sinar Grafika, Jakarta, 2003. , Politik Terhadap Legislatif Mengenai Penanggulangan Terhadap Suatu Kejahatan Terhadap Penggunaan Pidana Penjara, Badan Kencana Utama, Semarang, 2004.

Atmasasmita, Romli, Sistem Terkait Sistem Peradilan Pada Anak Di Indonesia, Jaya Utama, Jakarta, 2008.

Huda, Chairul, Bermula Pada Tidak Ada sebuah Pidana Dengan Tidak Ada Kesalahan Menuju Kepada Asas Tiada Pertanggungjawaban Terhadap Pidana Tidak Ada Kesalahan, Sinar Grafika, Jakarta, 2004.

Gultom, Maidin, Perlindungan Hukum Bagi Anak Pada Sistem Peradilan Anak yang ada di Indonesia, Refikatama, Bandung, 2009.

Saleh, Roeslan, Hukum Kepidanaan yang Merupakan sebuah Alat Untuk Mengkonfrontasikan Manusia, Agung Grafika, Jakarta, 2005. -, Stelsel Dkaitkan Terhadap Pola Kepidanaan Indonesia, Tunas Baru, Jakarta, 2004.

Suparni, Niniek, Eksistensi Terhadap Kepidanaan Dalam Penerapan Sebuah Denda Terkait Sistem Kepidanaan dan Pemidanaan, Sinar Grafiika, Jakarta, 2003.

\section{Perundang-Undangan}

Undang-Undang Nomor 11 Tahun 2012 Mengenai Sistem Peradilan Kepidanaan Anak.

Undang - Undang Dasar Negara Republik Indonesia Tahun 1945. 